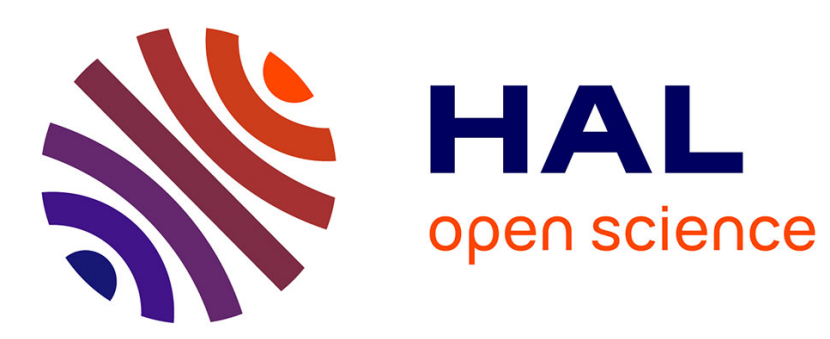

\title{
Study of the R-(Zr,W)-(O,N) $(\mathrm{R}=\mathrm{Y}, \mathrm{Nd}, \mathrm{Sm}, \mathrm{Gd}, \mathrm{Yb})$ oxynitride system
}

Franck Tessier, Pascal Maillard, Emmanuelle Orhan, François Cheviré

\section{To cite this version:}

Franck Tessier, Pascal Maillard, Emmanuelle Orhan, François Cheviré. Study of the R-(Zr,W)-(O,N) $(\mathrm{R}=\mathrm{Y}, \mathrm{Nd}, \mathrm{Sm}, \mathrm{Gd}, \mathrm{Yb})$ oxynitride system. Materials Research Bulletin, 2010, 45 (2), pp.97-102. 10.1016/j.materresbull.2009.10.003 . hal-00469836

\section{HAL Id: hal-00469836 https://hal.science/hal-00469836}

Submitted on 16 Feb 2016

HAL is a multi-disciplinary open access archive for the deposit and dissemination of scientific research documents, whether they are published or not. The documents may come from teaching and research institutions in France or abroad, or from public or private research centers.
L'archive ouverte pluridisciplinaire HAL, est destinée au dépôt et à la diffusion de documents scientifiques de niveau recherche, publiés ou non, émanant des établissements d'enseignement et de recherche français ou étrangers, des laboratoires publics ou privés. 


\title{
Study of the R-(Zr,W)-(O,N) (R= Y, Nd, Sm, Gd, Yb) oxynitride system
}

Franck Tessier ${ }^{\mathrm{a}, *}$, Pascal Maillard ${ }^{\mathrm{a}}$, Emmanuelle Orhan ${ }^{\mathrm{b}}$, François Cheviré ${ }^{\mathrm{a}}$

${ }^{a}$ UMR CNRS 6226 "Sciences Chimiques de Rennes", équipe "Verres et Céramiques", Université de Rennes 1, 35042 Rennes cedex, France

b Laboratoire Science des Procédés Céramiques et Traitements de Surface, UMR CNRS 6638, Université de Limoges, 123 Avenue Albert Thomas, 87060 Limoges cedex, France

* corresponding author: Franck.Tessier@univ-rennes1.fr $\quad$ Fax: +33223235683

\begin{abstract}
The replacement of tantalum by the couple $\mathrm{Zr} / \mathrm{W}$ within the $\mathrm{RTa}-\mathrm{O}-\mathrm{N}$ systems $(\mathrm{R}=\mathrm{Y}, \mathrm{Nd}, \mathrm{Sm}, \mathrm{Gd}$, $\mathrm{Yb}$ ), enables the preparation of novel oxide and oxynitride phases in the R-Zr-W-O-N system. $\mathrm{R}_{2} \mathrm{Zr}_{2-\mathrm{x}} \mathrm{W}_{\mathrm{x}} \mathrm{O}_{7+\mathrm{x}}$ oxides exhibit the fluorite-type $(\mathrm{x}<0.9)$ and scheelite $(\mathrm{x} \sim 1)$ structures. Corresponding oxynitride compositions are of the fluorite type and show different colors, for example in the case of ytterbium: pale yellow $(x=0.2$ or 0.25$)$, green $(x=0.5$ to 0.8$)$ and brown for the tungsten-rich samples $(\mathrm{x}=0.9,1)$. Photocatalytic activity measurements have been performed to investigate the overall water splitting behavior of these colored phases.
\end{abstract}




\section{Introduction}

Previous studies performed in our laboratory have shown that the reaction between rare-earth tantalates $\mathrm{RTaO}_{4}$ and ammonia flow at $900-950^{\circ} \mathrm{C}$ forms oxynitrides belonging to different structure types: perovskites $\mathrm{RTaON}_{2}$, pyrochlores $\mathrm{R}_{2} \mathrm{Ta}_{2} \mathrm{O}_{5} \mathrm{~N}_{2}$ and defect fluorites $\mathrm{RTa}(\mathrm{O}, \mathrm{N}, \square)_{4}$, depending on the size of the R element ( represents an anionic vacancy). A comparative study has been carried out with oxide powders prepared by ceramic and chimie douce routes to show how the nature of the oxide precursor is a crucial parameter that affect the nitridation products [1]. The pyrochlore structure is restricted to large rare-earths $(\mathrm{R}=\mathrm{Nd} \rightarrow \mathrm{Gd})$. For smaller $\mathrm{R}$ elements, thermal ammonolysis of reactive precursors elaborated from the citrate combustion route results in fluoritetype oxynitride solid solutions. X-ray and neutron diffraction studies evidence a totally disordered cubic fluorite unit cell which appears however not to be suitable for the structure refinement, thus revealing a more complex atom arrangement.

The synthesis of reactive nitridation precursors prepared using the citrate complexation/calcination route has also shown interest in the study of the system $\mathrm{R}_{2}$ Ta-O-N. Novel fluorite-type phases have been evidenced in the oxide series $\mathrm{R}_{2} \mathrm{TaO}_{5.5}(\mathrm{R}=\mathrm{Nd}-\mathrm{Yb}, \mathrm{Y})$ and oxynitride series $\mathrm{R}_{2.67} \mathrm{Ta}_{1.33}(\mathrm{O}, \mathrm{N}, \square)_{8}$. Chemical and optical analyses were performed to characterize these phases, as well as structural analogies with $\mathrm{R}_{2} \mathrm{WO}_{6}$ and $\mathrm{R}_{2} \mathrm{MoO}_{5}$ oxide families [2].

The incorporation of nitrogen within such oxide systems allows to shift the absorption edge towards visible wavalengths. In particular, our attention is focused on the panel of colors resulting from the nitridation treatment. Nitride and oxynitride materials display interesting optical properties which can be developped amongs pigments, UV absorbers or visible-light-driven photocatalysts [3-5].

In the context of the study of oxynitrides with defect-fluorite and pyrochlore structures, the purpose is to evidence a potential ordering in the cationic lattice. Following the results obtained in the R-TaO-N systems, we have studied the substitution of tantalum $\left(\mathrm{Ta}^{5+}\right)$ by the $\mathrm{Zr}^{4+} / \mathrm{W}^{6+}$ couple. These cations were chosen because of their compatible ionic radii, for example in 6-fold environment, 
$0.72 \AA$ and $0.60 \AA$ respectively, with that of tantalum $(0.64 \AA)$. No doubt that the $\mathrm{Zr} / \mathrm{W}$ substitution of tantalum atoms will engender a more complex cationic network, but the flexibility of the $\mathrm{Zr} / \mathrm{W}$ ratio will give the opportunity to have access to a large panel of compositions and colors. We know by experience that $\mathrm{Zr}^{\mathrm{IV}}$ and $\mathrm{W}^{\mathrm{VI}}$ are stable in a nitrided environment, for example in the compound $\mathrm{Zr}_{2} \mathrm{~N}_{2} \mathrm{O}$, in the scheelites $\mathrm{RWO}_{3} \mathrm{~N}$ or in the defect fluorites $\mathrm{R}_{2} \mathrm{~W}(\mathrm{O}, \mathrm{N}, \square)_{6}[6-8]$.

The syntheses using the citrate route offer a large diversity of compositions, so that we have chosen to modify, in particular, the cationic stoichiometry $\mathrm{Zr} / \mathrm{W}$ to attempt the preparation of oxynitride pyrochlores with the composition " ${ }_{6} \mathrm{~N}$ ". Starting with the attractive $\mathrm{R}_{2} \mathrm{Zr}_{1.5} \mathrm{~W}_{0.5} \mathrm{O}_{7.5}$ precursors targeted phases would have the corresponding general formula $\mathrm{R}_{2} \mathrm{Zr}_{1.5} \mathrm{~W}_{0.5} \mathrm{O}_{6} \mathrm{~N}$ and may crystallize in a $\mathrm{A}_{2} \mathrm{~B}_{2} \mathrm{X}_{6} \mathrm{X}^{\prime}$ pyrochlore structure.

Our study concerns mainly the structure and the resulting color of phases in the $\mathrm{R}_{2} \mathrm{Zr}_{2-\mathrm{x}} \mathrm{W}_{\mathrm{x}}(\mathrm{O}, \mathrm{N}, \square)_{8}$ system. Among some selected rare-earth elements (Y, Yb, Nd, Sm, Gd) we have chosen ytterbium to lead a complete study with $0 \leq \mathrm{x} \leq 1$ from the oxide $\mathrm{Yb}_{2} \mathrm{Zr}_{2} \mathrm{O}_{7}$ to the quaternary $\mathrm{Yb}_{2} \mathrm{ZrWO}_{8}$. The reaction of these oxides under ammonia gives rise to novel colored fluorite-type oxynitrides.

\section{Experimental}

Amorphous citrate route. It is not, strictly speaking, a classic sol-gel process in the usual sense that the gel is not formed by a metal-oxygen-metal network, but rather from calcination of metalorganic complexes, thus producing ultra fine reactive powders with an excellent chemical homogeneity [3]. Rare-earth oxides separately dissolved in concentrated hydrochloric acid (37\%, Merck), tungstic acid $\mathrm{H}_{2} \mathrm{WO}_{4}$ (Aldrich) in an ammonia solution and zirconyl nitrate hydrate $\mathrm{ZrO}\left(\mathrm{NO}_{3}\right)_{2}, 6 \mathrm{H}_{2} \mathrm{O}$ (Fluka) dissolved in water were used as starting materials. Citric acid $\left(\mathrm{C}_{6} \mathrm{H}_{8} \mathrm{O}_{7}, \geq\right.$ $99 \%$, Merck), dissolved in a minimum amount of water, was added to each solution in the proportion of one mole per cation valence, the addition being followed by a 20 min stirring step at $120^{\circ} \mathrm{C}$. As the complexation of cations by citric acid is improved at $\mathrm{pH} \geq 7$, the acidic solutions 
were neutralized with an ammonia solution (25\%, Merck) [9]. The solutions were then mixed together and the resulting solution stirred at $150^{\circ} \mathrm{C}$ for $20 \mathrm{~min}$ to promote polymerization. The liquid was progressively heated up to $250^{\circ} \mathrm{C}$, leading after $5 \mathrm{~h}$ to an expanded black solid residue, which was finally ground and then calcined at $600{ }^{\circ} \mathrm{C}$ in an alumina boat until total elimation of carbon.

Thermal ammonolysis. Nitridation reactions were carried out in alumina boats placed inside an electric furnace through which ammonia gas flowed with a flow rate of 40-50 $\mathrm{L} \mathrm{h}^{-1}$. The temperature was raised in the $600-1000{ }^{\circ} \mathrm{C}$ range with a heating rate of $10{ }^{\circ} \mathrm{C} \mathrm{min}^{-1}$. After a reaction time of $15 \mathrm{~h}$, the furnace was switched off and the nitrided powders were allowed to cool down to room temperature under nitrogen atmosphere.

X-ray diffraction. XRD powder patterns were recorded using a Philips PW3710 diffractometer operating with $\mathrm{Cu} \mathrm{K} \mathrm{K}_{\alpha}$ radiation $(\lambda=1.5418 \AA$ ). X'PERT softwares -Data Collector and Graphics and Identify- were used, respectively, for recording, analysis, and phase matching of the patterns. The lattice parameters were refined using Dicvol04 [10]. The Rietveld and pattern matching refinements were performed with FullProf available in the software package WinPLOTR [11].

Elemental analysis. Nitrogen and oxygen contents were determined with a LECO TC-436 analyzer using the inert gas fusion method. Nitrogen was detected as $\mathrm{N}_{2}$ by thermal conductivity and oxygen as $\mathrm{CO}_{2}$ by infrared detection. The apparatus was calibrated using $\mathrm{N}_{2}$ and $\mathrm{CO}_{2}$ gas (purity $\geq 99.95 \%$ ) as well as $\varepsilon-\mathrm{TaN}$ as a nitrogen standard [12].

UV-Vis spectrophotometry. Diffuse reflectance spectra were collected using a Varian Cary 100 Scan spectrometer equipped with the Varian WinUV software and an integrating sphere Labsphere (DRC-CA-30I). Prior to measurements, the absolute reflectance of the samples was calibrated with a certified "spectralon" standard (Labsphere Cie). Experimental data were collected within the 250$800 \mathrm{~nm}$ range with $1 \mathrm{~nm}$ step and $0.5 \mathrm{~s}$ integration time. The position of the absorption edge was determined graphically at the inflexion point of the curve and the value of the optical gap using the theory of Kubelka-Munk [13]. 
EDX. The cationic ratios were determined by electron microprobe analysis performed with a JEOL JSM 6400 electron microprobe.

\section{R-(Zr,W)-O oxide precursors}

\section{$\mathrm{Yb}_{2} \mathrm{Zr}_{2-\mathrm{x}} \mathrm{W}_{\mathrm{x}} \mathrm{O}_{7+\mathrm{x}}(\mathrm{x}=\mathbf{0} \rightarrow \mathbf{0 . 9})$ compositions}

Starting from the defect fluorite-type oxide $\mathrm{Yb}_{2} \mathrm{Zr}_{2} \mathrm{O}_{7}$ which structure is reported in literature [14], the substitution of zirconium atoms by tungsten leads to the formation of novel phases within the $\mathrm{Yb}_{2} \mathrm{Zr}_{2-\mathrm{x}} \mathrm{W}_{\mathrm{x}} \mathrm{O}_{7+\mathrm{x}}$ series. The compounds were prepared using the citrate route as previously described. After a calcination step at $600{ }^{\circ} \mathrm{C}$, all the XRD patterns present a similar poor crystallized profile similar to a pseudo-cubic symetry with large diffraction lines (Fig. 1). A thermal treatment carried out at $900{ }^{\circ} \mathrm{C}$ for 12 hours improves the crystallization of the precursor. We observe a structural change from defect fluorite to scheelite types with tungsten enrichment (Table 1). Thus, for compositions with $\mathrm{x}$ varying from 0 to 0.75 , corresponding XRD patterns are indexed in a fluorite-type unit cell (Fig. 1). We observe a mixture of the fluorite and scheelite types for the composition with $\mathrm{x}=0.8$ (Fig. 2) and a pure scheelite phase when $\mathrm{x}=0.9$ (Fig. 3). Thus, the composition $\mathrm{x}=0.75$ represents the limit of the stability of tungsten in 8 -fold defect site, so that a tetrahedral environnment becomes more appropriate with tungsten enrichment due to the small size of this cation $\left(\mathrm{rW}^{4}=0.42 \AA\right)$. In all cases, a heating step at $1000^{\circ} \mathrm{C}$ leads to the decomposition of the ternary phase into binary and ternary oxides.

\section{$\mathrm{R}_{2} \mathrm{ZrWO}_{8}(\mathrm{x}=1)$ compositions $(\mathrm{R}=\mathrm{Y}, \mathrm{Nd}, \mathrm{Sm}, \mathrm{Gd}, \mathrm{Yb})$}

Following the calcination of the products at $600^{\circ} \mathrm{C}, \mathrm{X}$-ray diffraction patterns present similar profiles for each of the rare-earth elements, those of a poor crystallized powder with a cubic or pseudo-cubic symetry (same as in Fig. 1). However, a greater crystallization state can be obtained if the materials are heated at higher temperatures $\left(\mathrm{T}>800^{\circ} \mathrm{C}\right)$. It was thus possible to evidence for each case the existence of a novel phase with the composition $\mathrm{R}_{2} \mathrm{ZrWO}_{8}$ that crystallizes in a 
tetragonal unit cell with the scheelite structure $\left[\mathrm{CaWO}_{4}, \mathrm{I}_{1} / \mathrm{a}, \mathrm{Z}=4\right]$ (Fig. 4). The refined unit cell parameters are shown in Table $2[10] . \mathrm{R}_{2} \mathrm{ZrWO}_{8}$ oxides are isostructural with $\mathrm{LiR}_{0.3} \mathrm{Y}_{0.7} \mathrm{~F}_{4}(\mathrm{R}=\mathrm{Tb}$, Ho) and $\mathrm{YNbO}_{4}$ phases [15-16].

In the case of ytterbium, a treatment at $950{ }^{\circ} \mathrm{C}$ (12 hours) leads to extra diffraction lines corresponding to the formation of a fluorite-type phase in mixture with the scheelite (Fig. 5). The fluorite phase $\left[\mathrm{CaF}_{2}, \mathrm{Fm} \overline{3} \mathrm{~m}\right]$ is isolated after a heating step at $850{ }^{\circ} \mathrm{C}$ in the presence of the mineralizer $\mathrm{NaCl}$ (Fig. 6). The indexation of the pattern leads to a cubic unit cell with parameter a $=$ 5.188(1) A. EDX measurements confirm that the cationic ratios are conserved in the scheelite phase $(\mathrm{Zr} / \mathrm{W}=1$ et $\mathrm{Yb} / \mathrm{Zr}=\mathrm{Yb} / \mathrm{W}=2)$, but are modified in the fluorite phase. This phase contains indeed less tungsten $(\mathrm{Zr} / \mathrm{W}=3)$, due to the partial sublimation of $\mathrm{WO}_{3}$ during the heating. The structure of the $\mathrm{Yb}_{2} \mathrm{ZrWO}_{8}$ scheelite was recently refined using the Rietveld method and leads to a tetragonal unit cell with parameters $\mathrm{a}=5.1584(5)$ and $\mathrm{c}=10.8246(6) \AA$ [17].

In this work, the structure of the yttrium-containing phase $\mathrm{Y}_{2} \mathrm{ZrWO}_{8}$ was refined using the Rietveld method. Yttrium cations are located in the $4 \mathrm{~b}$ position of the space group $\mathrm{I}_{1} / \mathrm{a}$, zirconium and tungsten in position $4 \mathrm{a}$ with an occupation rate of 0.125 each and anions occupy the general position. The parameters and the resulting data of the refinement are given in Tables 3 and 4, as well as the corresponding Rietveld difference plot in Figure 7. The structure is made of isolated tetrahedra $(\mathrm{Zr}, \mathrm{W}) \mathrm{O}_{4}$, linked together by 8 -coordinated yttrium atoms. The quite high values of the displacement parameters are related to the diffractometer used in this study (Biso $=2.53 \AA^{2}$ for zirconium and tungsten and $3 \AA^{2}$ for oxygen) and have been also observed when using a standard $\mathrm{Y}_{2} \mathrm{O}_{3}$ sample.

\section{Novel oxynitride phases in the $R-(Z r, W)-(O, N)$ system}

$$
\operatorname{Yb}_{2} Z_{2-x} W_{x}(\mathbf{O}, \mathbf{N}, \square)_{8}(x=0 \rightarrow 0,9)
$$

Nitridation reactions were carried out at temperatures between 550 and $1000^{\circ} \mathrm{C}$ for each composition. To take advantage of the reactivity of the powders, poorly crystallized samples were 
reacted under $\mathrm{NH}_{3}$ at $600^{\circ} \mathrm{C}$. Note that the same precusors, with a higher crystallinity obtained after a heating step at $900^{\circ} \mathrm{C}$, require higher nitriding temperatures that involve tungsten reduction. The reduction phenomenon is confirmed by the dark green or black color of the powder. The most interesting results are obtained with a poorly crystallized sample when $\mathrm{x}=[0-0.8]$. Unlike for tungsten-rich samples $(\mathrm{x}=0.9,1)$, novel oxynitride phases were isolated staring from crystallized precursors.

For the compositions with $\mathrm{x}$ varying from 0 to 0.8 , the results of the nitridation performed at $700^{\circ} \mathrm{C}$ during 15 hours are given in Tables 5 and 6. Only the composition $\mathrm{Yb}_{2} \mathrm{Zr}_{2} \mathrm{O}_{7}(\mathrm{x}=0)$ does not react under flowing ammonia, no significant amount of nitrogen was measured.

For the low tungsten content compositions $(\mathrm{x}=0.2$ and 0.5$)$, a pale yellow fluorite-type oxynitride phase is obtained (Fig. 8), respectively with the corresponding formulas $\mathrm{Yb}_{2} \mathrm{Zr}_{1.8} \mathrm{~W}_{0.2} \mathrm{O}_{6.43} \mathrm{~N}_{0.52} \square_{1.05}$ and $\mathrm{Yb}_{2} \mathrm{Zr}_{1.75} \mathrm{~W}_{0.25} \mathrm{O}_{5.60} \mathrm{~N}_{1.10}{ }_{1.30}$. It was not possible to enrich the composition with nitrogen, as a longer reaction step ( 2 cycles of 15 hours) or a reaction at temperatures higher than $700^{\circ} \mathrm{C}$ induce some tungsten reduction characterized by the green shade of the powder. Above $900^{\circ} \mathrm{C}$, the powder turns black with the formation of the binary nitride $\mathrm{W}_{2} \mathrm{~N}$ identified by XRD. The compositions $\mathrm{x}=$ 0.2 and 0.25 present a different yellow intensity, explained by the position of the repective absorption edge at 414 and $455 \mathrm{~nm}$ (Fig. 9). The large spectral deviation observed on the spectra confirms also the poor crystallization state of the samples. The corresponding La* $\mathrm{b}^{*}$ coordinates indicate a more intense yellow hue for the oxynitride $\mathrm{Yb}_{2} \mathrm{Zr}_{1.75} \mathrm{~W}_{0.25} \mathrm{O}_{5.60} \mathrm{~N}_{1.10} \square_{1.30}(\mathrm{~L}=94, \mathrm{a}=5, \mathrm{~b}=$ 30) compared to $\mathrm{Yb}_{2} \mathrm{Zr}_{1.8} \mathrm{~W}_{0.2} \mathrm{O}_{6.43} \mathrm{~N}_{0.52} \square_{1.05}(\mathrm{~L}=100, \mathrm{a}=2, \mathrm{~b}=17)$ directly related to the higher nitrogen content. EDX measurements have been carried out with the oxynitride $\mathrm{Yb}_{2} \mathrm{Zr}_{1.75} \mathrm{~W}_{0.25} \mathrm{O}_{5.60} \mathrm{~N}_{1.10} \square_{1.30}$ and show after nitridation no modification in the cationic ratios ( $\mathrm{Yb} / \mathrm{Zr}$ $=1.14 \pm 0.1$ et $\mathrm{Zr} / \mathrm{W}=7 \pm 0.1)$.

The oxynitride phases corresponding to $\mathrm{x}=0.5,0.75$ and 0.8 all display a strong green color as soon as the lowest nitridation temperatures $\left(600^{\circ} \mathrm{C}\right)$ are reached, in agreement with a tungsten reduction phenomenon. The possibility of ordering in the cationic network was studied in the case $\mathrm{x}$ 
$=0.5$. The objective was to reach the $\mathrm{Yb}_{2} \mathrm{Zr}_{1.5} \mathrm{~W}_{0.5} \mathrm{O}_{6} \mathrm{~N}$ composition in the pyrochlore-type $\mathrm{A}_{2} \mathrm{~B}_{2} \mathrm{X}_{6} \mathrm{X}^{\prime}$. After nitridation of the corresponding crystallized precursor, a green sample was indexed in a fluorite unit cell. Starting from a poor crystallized sample, the $\mathrm{Yb}_{2} \mathrm{Zr}_{1.5} \mathrm{~W}_{0.5} \mathrm{O}_{6.01} \mathrm{~N}_{1.00 \square 0.99}(2.03$ wt $\mathrm{N} \%$ ) phase is obtained at $600^{\circ} \mathrm{C}$, but also in the fluorite-type. Although this experimental composition is of the " ${ }_{6} \mathrm{~N} "$ stoichiometry and despite of the different atomic numbers of the cations $\left(\mathrm{Z}_{\mathrm{Yb}}=70, \mathrm{Z}_{\mathrm{Zr}}=40, \mathrm{Z}_{\mathrm{W}}=74\right)$, no superstructure diffraction line related to some ordering is visible on the diffraction pattern. We observe for those samples an apparent fluorite-type structure where both cationic and anionic positions are disordered. Besides, due to the difference in the cationic radii of ytterbium and zirconium in coordinence $8\left(\mathrm{rYb}^{8}=0.98, \mathrm{rZr}^{8}=0.84\right)$ [18], it is quite surprising to find an element like tungsten in a cubic environment, even defective.

When $\mathrm{x}$ reaches 0.75 and 0.8 , reduction of tungsten occurs as soon as $600^{\circ} \mathrm{C}$ producing respectively dark green (" $\left.\mathrm{Yb}_{2} \mathrm{Zr}_{1.25} \mathrm{~W}_{0.75} \mathrm{O}_{5.75} \mathrm{~N}_{1.33} \square 0.92 "\right)$ and brown (" $\left.\mathrm{Yb}_{2} \mathrm{Zr}_{1.2} \mathrm{~W}_{0.8} \mathrm{O}_{5.67} \mathrm{~N}_{1.42} \square 0.91 "\right)$ powders.

Regarding the tungsten-rich compositions $(\mathrm{x}=0.9$ and 1$)$, the reduction is visible as soon as the lowest temperatures of $600^{\circ} \mathrm{C}$ if the reaction is performed on the pseudo-cubic precursor (poor crystallized sample). Unlike the previous cases $(\mathrm{x}=0$ to 0.8$)$, it was only possible to prepare a single phase brown oxynitride powder when using a crystallized precursor. A fluorite phase $\mathrm{Yb}_{2} \mathrm{Zr}_{1.1} \mathrm{~W}_{0.9} \mathrm{O}_{4.83} \mathrm{~N}_{2.05} \square_{1.12}$ is obtained at $700^{\circ} \mathrm{C}$. The higher stability of tungsten towards ammonolysis is here evidenced, when this element is located in the tetrahedral sites of the scheelite corresponding oxide precursor. Tungsten is thus less sensitive to the reducing effect of ammonia during nitridation.

\section{$\mathrm{R}_{2} \mathrm{ZrW}(\mathrm{O}, \mathrm{N}, \infty)_{8} \quad(x=1)$ compositions $(\mathrm{R}=\mathrm{Y}, \mathrm{Nd}, \mathrm{Sm}, \mathrm{Gd}, \mathrm{Yb})$}

For this stoichiometry, only the crystallized precursors (scheelite type) have been nitrided. Indeed, amorphous oxides, even if they can be reacted under ammonia at lower temperatures, lead here only to amorphous oxynitrides difficult to crystallize and then to characterize. Thus, we have studied the nitridation of the $\mathrm{R}_{2} \mathrm{ZrWO}_{8}(\mathrm{R}=\mathrm{Y}, \mathrm{Yb}, \mathrm{Sm}, \mathrm{Gd}$ and $\mathrm{Nd})$ oxides at temperatures between 650 and 
$850^{\circ} \mathrm{C}$. For all the studied rare-earth, a cubic unit cell of the fluorite-type (space group Fm $\overline{3} \mathrm{~m}$ ) characterizes each oxynitride. Corresponding parameters calculated on samples nitrided at $800^{\circ} \mathrm{C}$ are given in Table 7. Such a unit cell $(\mathrm{a} \sim 5 \AA)$ involves the same cubic site for all the cations, despite of size differences [18]. For example, in 8-fold coordinated site $\mathrm{rY}^{8}$ equals 1.015 and $\mathrm{rZr}^{8}$ equals $0, .84$ (tungsten is not listed for that environment). Nevertheless, the crystallisation state of the oxynitride phases is not sufficient (large line basis) to perform a structural refinement (Fig. 10). In this system, the oxynitride phase forms between $650^{\circ} \mathrm{C}$ and $750^{\circ} \mathrm{C}$, and a subsequent nitrogen enhancement occurs with increasing nitridation time and temperature, resulting in the formation of solid solutions. After nitridation the compounds are brown orange and darken with increasing nitrogen contents. There is a threshold, depending on each rare-earth element, for which the color is altered with some reduced tungsten under the form of $\mathrm{W}_{2} \mathrm{~N}$. For example, in the case of $\mathrm{Y}_{2} \mathrm{ZrW}(\mathrm{O}, \mathrm{N}, \square) 8$, the presence of $\mathrm{W}_{2} \mathrm{~N}$ is detected as soon as $850^{\circ} \mathrm{C}$ after a nitridation step of $48 \mathrm{~h}$.

The progressive transition from the scheelite precursor to the fluorite-type oxynitride is displayed in Fig. 10 in the case of ytterbium. Reactions were carried out at $700^{\circ} \mathrm{C}$ under ammonia from 2 to 15 hours. Once the diffraction lines at $33.2^{\circ}$ and $57.5^{\circ}(2 \theta)$ dissapeared, a single phase oxynitride is obtained. In a similar way to the study performed on the system $\mathrm{RTa}(\mathrm{O}, \mathrm{N}, \square)_{4}[1]$, we have evidence the existence of a solid solution domain with a maximum nitrogen enrichment obtained after a 48 hours reaction step. The composition evolves from $\mathrm{Yb}_{2} \mathrm{ZrWO}_{5.14} \mathrm{~N}_{1.91} \square_{0.95}\left(700^{\circ} \mathrm{C}, 15 \mathrm{~h}, \mathrm{a}=5.156(1)\right.$ $\AA$ ) to $\mathrm{Yb}_{2} \mathrm{ZrWO}_{4.38} \mathrm{~N}_{2.41} \square_{1.21}\left(800^{\circ} \mathrm{C}, 48 \mathrm{~h}, \mathrm{a}=5.148(1) \AA\right)$. The colors turn from pale brown to brown respectively. The cationic ratios $\mathrm{Yb} / \mathrm{Zr}=2$ and $\mathrm{Zr} / \mathrm{W}=1$ are kept after nitridation according to EDX analyses.

The nitridation of the yttrium phase $\mathrm{Y}_{2} \mathrm{ZrWO}_{8}$ at $700^{\circ} \mathrm{C}(15 \mathrm{~h})$ leads also to a novel pale brown oxynitride $\mathrm{Y}_{2} \mathrm{ZrWO}_{5.08} \mathrm{~N}_{1.94 \square 0.98}(4.85 \mathrm{wt} \mathrm{N} \%, \mathrm{a}=5.190(2) \AA$ ). It was possible to enrich this phase 
with nitrogen and to keep the same fluorite structure giving rise to a solid solution. At $800^{\circ} \mathrm{C}$, the oxynitride $\mathrm{Y}_{2} \mathrm{ZrWO}_{4.09} \mathrm{~N}_{2.60} \square_{1.31}$ reaches 6.58 wt N \% (a = 5.188(2) $\AA$ ).

Nitrides and oxynitrides represent a group of ceramic materials of increasing technological properties, with applications, for example, as optical materials. The incorporation of nitrogen within an oxide allows to shift the absorption edge towards visible wavalengths. Interesting properties are developed in particular to set up a novel generation of visible-light-driven photocatalysts [19]. This application emerged few years ago as an original way to produce hydrogen from the decomposition of water. Following a large screening of nitride and oxynitride compositions, this approach has shown some promising results which study is actually in progress [5]. Two samples $\mathrm{Y}_{2} \mathrm{ZrWO}_{5.08} \mathrm{~N}_{1.94 \square 0.98}$ and $\mathrm{Yb}_{2} \mathrm{ZrWO}_{5.14} \mathrm{~N}_{1.91 \square 0.95}$ were tested for the overall water splitting reaction. Both of them manifest a brown color, they absorb a large part of the visible domain and are potential candidates for such an application. Unfortunately, no photocatalytic activity was evidenced for these two phases. We attribute this result, to our knowledge, to the poor crystallization state of the samples and to the presence of vacations in the anionic network, which can act as recombination centers for electrons and holes.

\section{Conclusion}

Using precursors prepared through the amorphous citrate route, the structure and color of new oxynitrides and oxides within the $\mathrm{R}_{2} \mathrm{Zr}_{2-\mathrm{x}} \mathrm{W}_{\mathrm{x}}(\mathrm{O}, \mathrm{N}, \square)_{8}$ system have been characterized. The nitridation of $\mathrm{R}_{2} \mathrm{ZrWO}_{8}$ scheelite phases leads to fluorite-type oxynitrides and to the formation of solid solutions with nitrogen enrichment. With increasing tungsten content, the color of the phase turns from pale yellow to green and brown. The presence of reduced tugsten as $\mathrm{W}_{2} \mathrm{~N}$ was confirmed by the green or black color of the powders. An attempt, but inconclusive, was made to measure the photocatalytic activity for the overall water splitting reaction. 


\section{Acknowledgement}

The authors thank the group of Pr. Kazunari Domen at the University of Tokyo for the overall water splitting tests performed on our samples. 


\section{References}

[1] P. Maillard, F. Tessier, E. Orhan, F. Cheviré, R. Marchand, Chem. Mater. 17 (2005) 152-156

[2] P. Maillard, O. Merdrignac-Conanec, F. Tessier, Mater. Res. Bull. 43 (2008) 30-37

[3] F. Tessier, R. Marchand, J. Solid State Chem. 171 (2003) 143-151

[4] F. Cheviré, F. Tessier, R. Marchand, Eur. J. Inorg. Chem. (2006) 1223-1230

[5] F. Tessier, P. Maillard, F. Cheviré, K. Domen, S. Kikkawa, J. Ceram. Soc. Jap. 117 (2009) $1-5$

[6] F. Cheviré, F. Tessier, R. Marchand, Mater. Res. Bull. 39 (2004) 1091-1101

[7] N. Diot, O. Larcher, R. Marchand, J.-Y. Kempf, P. Macaudière J. Alloys Compd. 323 (2001) $45-48$

[8] F. Cheviré, F. Clabau, O. Larcher, E. Orhan, F. Tessier, R. Marchand, Solid State Sci. 11 (2009) 533-536

[9] A. Douy, P. Odier, Mater. Res. Bull. 24 (1989) 1119-1126

[10] A. Boultif, D. Louer, J. Appl. Cryst. 37 (2004) 724-731

[11] T. Roisnel, J. Rodriguez-Carvajal, Mater. Sci. Forum 378-381 (2001) 118-123

[12] W. Gruner, B. Wollein, W. Lengauer, Microchim. Acta 146 (2004) 1

[13] D. Kubelka, L. Munk, Z. Teck. Physik. 12 (1931) 593-601

[14] K. Daido, Y. Akira, M. Toshihiro, E. Shuichi, K. Fumikazu, K. Kichiro, Solid State Ionics 50(3-4) (1992) 291-301

[15] K. Jaer, J. Als-Nielsen, I. Laursen, F. Krebs Larsen, J. Phys.: Condens. Matter 1 (1989) 57435757

[16] O. Yamaguchi, J. Am. Ceram. Soc. 68(10) (1985) C275-276

[17] P. Maillard, P. Bénard-Rocherullé, T. Roisnel, Powder Diffraction 22(4) (2007) 344-350

[18] R.D. Shannon, C.T. Prewitt, Acta Cryst. B26 (1970) 1046-1048

[19] K.Maeda, K. Domen, J. Phys. Chem. C 111 (2007) 7851-7861 
Table 1

Structure and unit cell parameters of the phases in the $\mathrm{Yb}_{2} \mathrm{Zr}_{2-\mathrm{x}} \mathrm{W}_{\mathrm{x}} \mathrm{O}_{7+\mathrm{x}}$ series heated at $900^{\circ} \mathrm{C}$.

\begin{tabular}{ccc}
\hline Composition & XRD $\left(\mathbf{9 0 0}^{\circ} \mathbf{C}\right)$ & Parameters $(\AA)$ \\
\hline $\mathrm{Yb}_{2} \mathrm{Zr}_{2} \mathrm{O}_{7}$ & fluorite & $\mathrm{a}=5.160(2)$ \\
$\mathrm{Yb}_{2} \mathrm{Zr}_{1.8} \mathrm{~W}_{0.2} \mathrm{O}_{7.2}$ & fluorite & $\mathrm{a}=5.164(2)$ \\
$\mathrm{Yb}_{2} \mathrm{Zr}_{1.75} \mathrm{~W}_{0.25} \mathrm{O}_{7.25}$ & fluorite & $\mathrm{a}=5.169(5)$ \\
$\mathrm{Yb}_{2} \mathrm{Zr}_{1.5} \mathrm{~W}_{0.5} \mathrm{O}_{7.5}$ & fluorite & $\mathrm{a}=5.174(2)$ \\
$\mathrm{Yb}_{2} \mathrm{Zr}_{1.25} \mathrm{~W}_{0.75} \mathrm{O}_{7.75}$ & fluorite & $\mathrm{a}=5.174(4)$ \\
$\mathrm{Yb}_{2} \mathrm{Zr}_{1.2} \mathrm{~W}_{0.8} \mathrm{O}_{7.8}$ & fluorite + scheelite & - \\
$\mathrm{Yb}_{2} \mathrm{Zr}_{1.1} \mathrm{~W}_{0.9} \mathrm{O}_{7.9}$ & scheelite & $\mathrm{a}=5.147(3) \mathrm{c}=10.784(8)$ \\
\hline
\end{tabular}


Table 2

Comparison of the tetragonal unit cell parameters between $\mathrm{R}_{2} \mathrm{ZrWO}_{8}$ phases and isostructural phases.

\begin{tabular}{|c|c|c|}
\hline \multirow{2}{*}{ Composition } & a & Parameters $(\AA)$ \\
\cline { 2 - 3 } & $5.153(2)$ & $10.821(8)$ \\
\hline $\mathrm{Yb}_{2} \mathrm{ZrWO}_{8}$ & $5.194(1)$ & $10.908(4)$ \\
\hline $\mathrm{Y}_{2} \mathrm{ZrWO}_{8}$ & $5.229(3)$ & $11.152(4)$ \\
\hline $\mathrm{Sm}_{2} \mathrm{ZrWO}_{8}$ & $5.251(4)$ & $11.07(1)$ \\
\hline $\mathrm{Gd}_{2} \mathrm{ZrWO}_{8}$ & $5.259(5)$ & $11.263(6)$ \\
\hline $\mathrm{Nd}_{2} \mathrm{ZrWO}_{8}$ & $5.146(1)$ & $10.758(1)$ \\
\hline $\mathrm{LiHo}_{0.3} \mathrm{Y}_{0.7} \mathrm{~F}_{4}$ & 5.164 & 10.864 \\
\hline $\mathrm{YNbO}_{4}$ & & \\
\hline
\end{tabular}


Table 3

Details of the Rietveld refinement for the $\mathrm{Y}_{2} \mathrm{ZrWO}_{8}$ phase

\begin{tabular}{cc}
\hline Formula & Y $_{2} \mathbf{Z r W O} \mathbf{8}$ \\
\hline $\mathrm{a}(\AA)$ & $5.20295(5)$ \\
$\mathrm{b}(\AA)$ & $10.92506(5)$ \\
$\mathrm{V}(\AA)$ & 295.75 \\
Space group & $\mathrm{I}_{1} / \mathrm{a}$ \\
$\mathrm{Z}$ & 4 \\
$\lambda .(. \AA \quad)$ & 1.5418 \\
Number of reflections & 55 \\
Number of parameters & 5 \\
Atoms number & 4 \\
Profile function & $\mathrm{TCH}$ \\
$\mathrm{R}_{\mathrm{p}}$ & 15.3 \\
$\mathrm{R}_{\mathrm{wp}}$ & 16.7 \\
$\mathrm{R}_{\exp }$ & 11.49 \\
$\chi^{2}$ & 2.12 \\
\hline
\end{tabular}


Table 4

Fractional atomic coordinates and isotropic displacement parameters for the $\mathrm{Y}_{2} \mathrm{ZrWO}_{8}$ phase

\begin{tabular}{|c|c|c|c|c|c|c|}
\hline Atom & Position & $\mathbf{x}$ & $\mathbf{y}$ & $\mathbf{z}$ & Occupation & Biso $\left(\AA^{2}\right)$ \\
\hline $\mathrm{Y}$ & $4 \mathrm{a}$ & 0 & $1 / 4$ & $1 / 8$ & 0.25 & $1.34(14)$ \\
\hline $\mathrm{Zr}$ & $4 \mathrm{~b}$ & 0 & $1 / 4$ & $5 / 8$ & 0.125 & $2.53(12)$ \\
\hline $\mathrm{W}$ & $4 \mathrm{~b}$ & 0 & $1 / 4$ & $5 / 8$ & 0.125 & $2.53(12)$ \\
\hline $\mathrm{O}$ & $16 \mathrm{f}$ & $0.267(1)$ & $0.550(4)$ & $0.466(1)$ & 1 & $3.00(43)$ \\
\hline
\end{tabular}


Table 5

Nitridation results in the $\mathrm{Yb}_{2} \mathrm{Zr}_{2-\mathrm{x}} \mathrm{W}_{\mathrm{x}}(\mathrm{O}, \mathrm{N}, \square)_{8}$ system.

\begin{tabular}{|c|c|c|c|c|}
\hline Ratio & $\begin{array}{l}\text { Nitridation } \\
\text { parameters }\end{array}$ & observed & Parameter (Å) & Color \\
\hline $\mathrm{Zr}_{1.8} \mathrm{~W}_{0.2}$ & $700^{\circ} \mathrm{C}-15 \mathrm{~h}$ & $\begin{array}{c}\text { Poor crystallized } \\
\text { fluorite }\end{array}$ & - & \\
\hline $\mathrm{Zr}_{1.75} \mathrm{~W}_{0.25}$ & $700^{\circ} \mathrm{C}-15 \mathrm{~h}$ & $\begin{array}{l}\text { Poor crystallized } \\
\text { fluorite }\end{array}$ & - & \\
\hline $\mathrm{Zr}_{1.5} \mathrm{~W}_{0.5}$ & $700^{\circ} \mathrm{C}-15 \mathrm{~h}$ & $\begin{array}{l}\text { Poor crystallized } \\
\text { fluorite }\end{array}$ & - & \\
\hline $\mathrm{Zr}_{1.25} \mathrm{~W}_{0.75}$ & $700^{\circ} \mathrm{C}-15 \mathrm{~h}$ & $\begin{array}{l}\text { Poor crystallized } \\
\text { fluorite }\end{array}$ & - & \\
\hline $\mathrm{Zr}_{1.2} \mathrm{~W}_{0.8}$ & $700^{\circ} \mathrm{C}-15 \mathrm{~h}$ & $\begin{array}{l}\text { Poor crystallized } \\
\text { fluorite }\end{array}$ & - & \\
\hline $\mathrm{Zr}_{1.1} \mathrm{~W}_{0.9}$ & $700^{\circ} \mathrm{C}-15 \mathrm{~h}$ & Fluorite & $5.144(1)$ & \\
\hline $\mathrm{ZrW}$ & $700^{\circ} \mathrm{C}-15 \mathrm{~h}$ & Fluorite & $5.148(2)$ & \\
\hline
\end{tabular}

Table 6 
Nitrogen analysis and corresponding formulas of the $\mathrm{Yb}_{2} \mathrm{Zr}_{2-\mathrm{x}} \mathrm{W}_{\mathrm{x}}(\mathrm{O}, \mathrm{N}, \square) 8$ phases prepared at $700^{\circ} \mathrm{C}$.

\begin{tabular}{cccc}
\hline Ratio & Nitridation parameters & wt. \% N & Formulation \\
\hline $\mathrm{Zr}_{1.8} \mathrm{~W}_{0.2}$ & $700^{\circ} \mathrm{C}-15 \mathrm{~h}$ & $1.1_{0}$ & $\mathrm{Yb}_{2} \mathrm{Zr}_{1.8} \mathrm{~W}_{0.2} \mathrm{O}_{6.43} \mathrm{~N}_{0.52} \square 1.05$ \\
$\mathrm{Zr}_{1.75} \mathrm{~W}_{0.25}$ & $700^{\circ} \mathrm{C}-15 \mathrm{~h}$ & 2.34 & $\mathrm{Yb}_{2} \mathrm{Zr}_{1.75} \mathrm{~W}_{0.25} \mathrm{O}_{5.60} \mathrm{~N}_{1.10} \square_{1.30}$ \\
$\mathrm{Zr}_{1.5} \mathrm{~W}_{0.5}$ & $700^{\circ} \mathrm{C}-15 \mathrm{~h}$ & 1.85 & $\mathrm{Yb}_{2} \mathrm{Zr}_{1.5} \mathrm{~W}_{0.5} \mathrm{O}_{6.14} \mathrm{~N}_{0.91} \square_{0.95}$ \\
$\mathrm{Zr}_{1.25} \mathrm{~W}_{0.75}$ & $700^{\circ} \mathrm{C}-15 \mathrm{~h}$ & $1.9_{0}$ & $\mathrm{Yb}_{2} \mathrm{Zr}_{1.25} \mathrm{~W}_{0.75} \mathrm{O}_{6.30} \mathrm{~N}_{0.97} \square 0.73$ \\
$\mathrm{Zr}_{1.2} \mathrm{~W}_{0.8}$ & $700^{\circ} \mathrm{C}-15 \mathrm{~h}$ & $2.8_{1}$ & $\mathrm{Yb}_{2} \mathrm{Zr}_{1.2} \mathrm{~W}_{0.8} \mathrm{O}_{5.66} \mathrm{~N}_{1.43} \square 0.91$ \\
$\mathrm{Zr}_{1.1} \mathrm{~W}_{0.9}$ & $700^{\circ} \mathrm{C}-15 \mathrm{~h}$ & $4.0_{2}$ & $\mathrm{Yb}_{2} \mathrm{Zr}_{1.1} \mathrm{~W}_{0.9} \mathrm{O}_{4.83} \mathrm{~N}_{2.05} \square_{1.12}$ \\
$\mathrm{ZrW}$ & $700^{\circ} \mathrm{C}-15 \mathrm{~h}$ & 3.66 & $\mathrm{Yb}_{2} \mathrm{ZrWO}_{5.14} \mathrm{~N}_{1.91 \square 0.95}$ \\
\hline
\end{tabular}




\section{Table 7}

Cubic parameter of the $\mathrm{R}_{2} \mathrm{ZrW}(\mathrm{O}, \mathrm{N}, \square) 8$ phases prepared at $800^{\circ} \mathrm{C}$.

\begin{tabular}{|c|c|}
\hline Compound & Parameter $(\AA)$ \\
\hline $\mathrm{Yb}_{2} \mathrm{ZrWO}_{4.38} \mathrm{~N}_{2.41} \square_{1.21}$ & $5.148(1)$ \\
\hline $\mathrm{Y}_{2} \mathrm{ZrW} \mathrm{O}{ }_{4.09} \mathrm{~N}_{2.60} \square_{1.31}$ & $5.188(2)$ \\
\hline $\mathrm{Gd}_{2} \mathrm{ZrWO}_{4.0} \mathrm{~N}_{2.7} \square_{1.3}$ & $5.249(1)$ \\
\hline $\mathrm{Sm}_{2} \mathrm{ZrWO}_{4.1} \mathrm{~N}_{2.6} \square_{1.3}$ & $5.271(2)$ \\
\hline $\mathrm{Nd}_{2} \mathrm{ZrWO}_{4.2} \mathrm{~N}_{2.5} \square_{1.2}$ & $5.310(1)$ \\
\hline
\end{tabular}




\section{Figures captions}

Fig. 1: XRD patterns of the $\mathrm{Yb}_{2} \mathrm{Zr}_{1.25} \mathrm{~W}_{0.75} \mathrm{O}_{7.75}$ oxide after calcination at 600 and $900^{\circ} \mathrm{C}$.

Fig. 2. XRD pattern of the $\mathrm{Yb}_{2} \mathrm{Zr}_{1.2} \mathrm{~W}_{0.8} \mathrm{O}_{7.8}$ oxide after calcination at $900^{\circ} \mathrm{C}$.

Fig. 3: XRD pattern of the $\mathrm{Yb}_{2} \mathrm{Zr}_{1.1} \mathrm{~W}_{0.9} \mathrm{O}_{7.9}$ scheelite at 600 and $900^{\circ} \mathrm{C}$.

Fig. 4: XRD pattern of the $\mathrm{Yb}_{2} \mathrm{ZrWO}_{8}$ scheelite, obtained at $900^{\circ} \mathrm{C}(12 \mathrm{~h})$

Fig. 5: $\mathrm{XRD}$ pattern after heating of $\mathrm{Yb}_{2} \mathrm{ZrWO}_{8}$ at $950^{\circ} \mathrm{C}(12 \mathrm{~h})$ : presence of fluorite-type and scheelite phases.

Fig. 6: XRD pattern of the fluorite phase obtained after heating at $850^{\circ} \mathrm{C}(12 \mathrm{~h})$ in presence of a mineralizer

Fig. 7: Rietveld difference plot for $\mathrm{Y}_{2} \mathrm{ZrWO}_{8}$; observed (dotted line), calculated (black full line). The vertical markers correspond to the position of the Bragg reflections.

Fig. 8: XRD pattern of the $\mathrm{Yb}_{2} \mathrm{Zr}_{1.8} \mathrm{~W}_{0.2} \mathrm{O}_{6.43} \mathrm{~N}_{0.52}{ }_{1.05}$ phase obtained at $700^{\circ} \mathrm{C}$.

Fig. 9 : Diffuse reflectance spectra of the oxynitrides $\mathrm{Yb}_{2} \mathrm{Zr}_{1.8} \mathrm{~W}_{0.2} \mathrm{O}_{6.43} \mathrm{~N}_{0.52}{ }_{1.05}(\mathrm{x}=0.20)$ and $\mathrm{Yb}_{2} \mathrm{Zr}_{1.75} \mathrm{~W}_{0.25} \mathrm{O}_{5.60} \mathrm{~N}_{1.10 \square 1.30}(\mathrm{x}=0.25)$ prepared at $700^{\circ} \mathrm{C}$.

Fig. 10 : Evolution of the crystal structure with the nitridation time of $\mathrm{Yb}_{2} \mathrm{ZrWO}_{8}$ at $700^{\circ} \mathrm{C}$. Arrows underline the progressive loss of scheelite phase. 


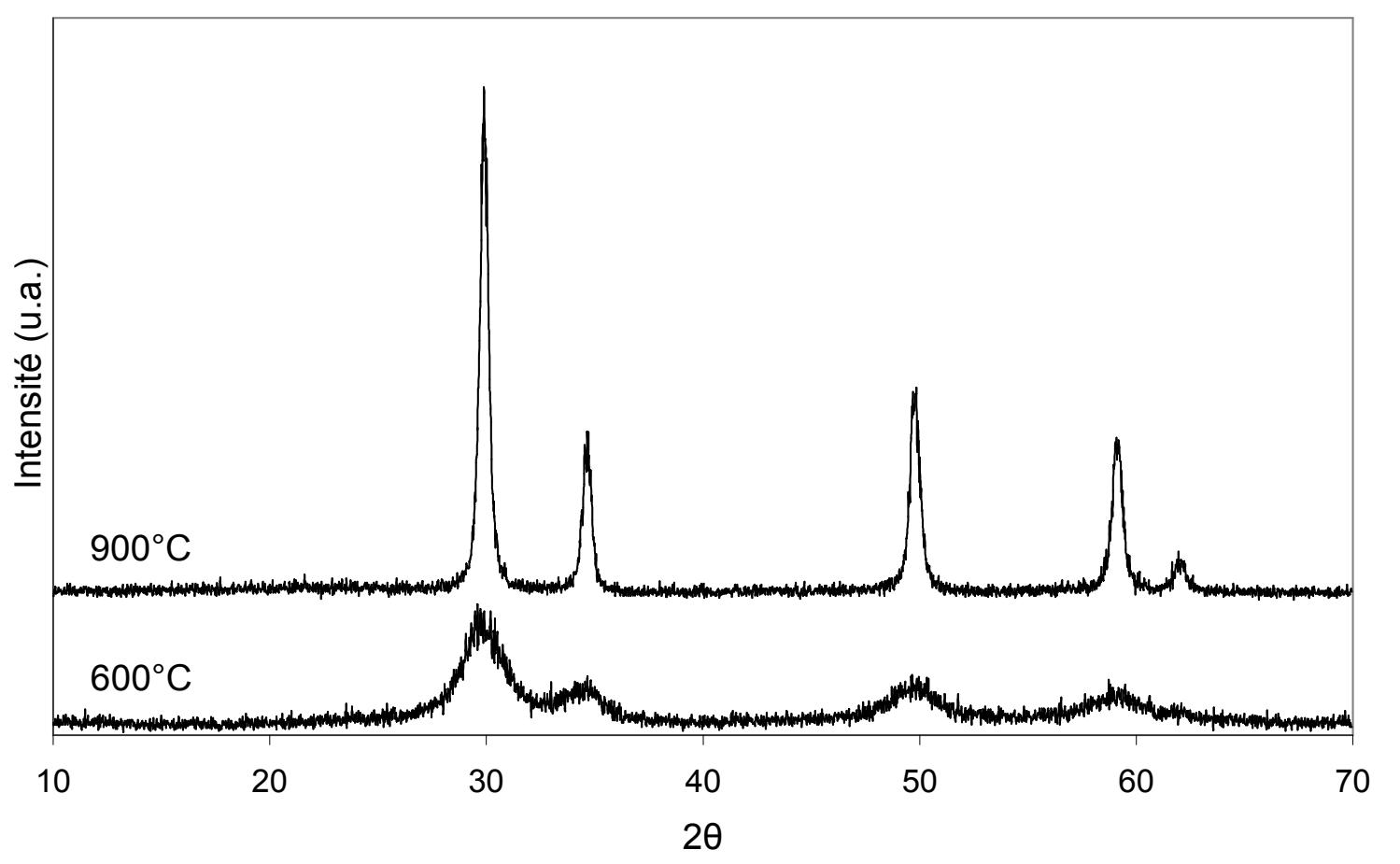

Fig. 1 


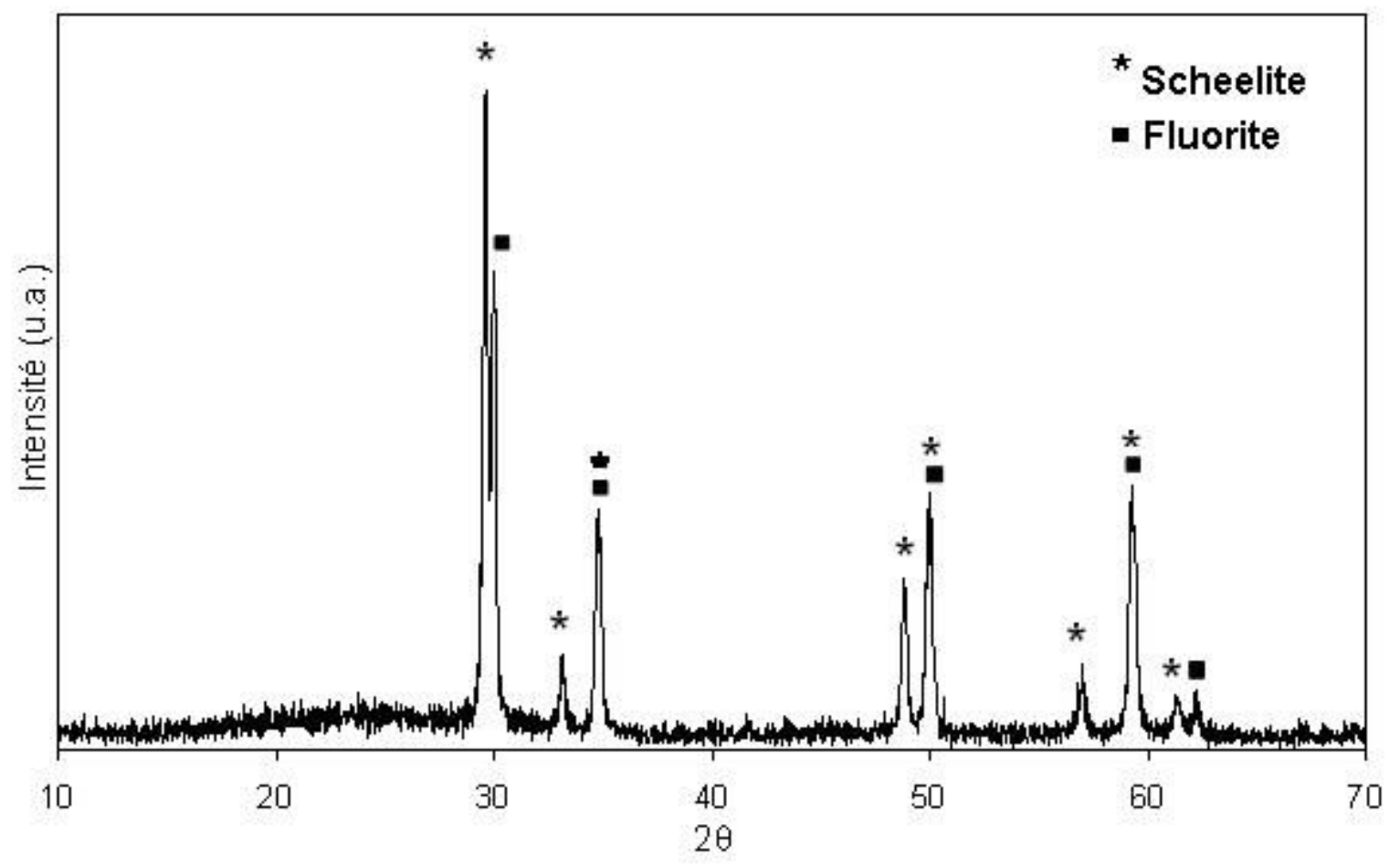

Fig. 2 


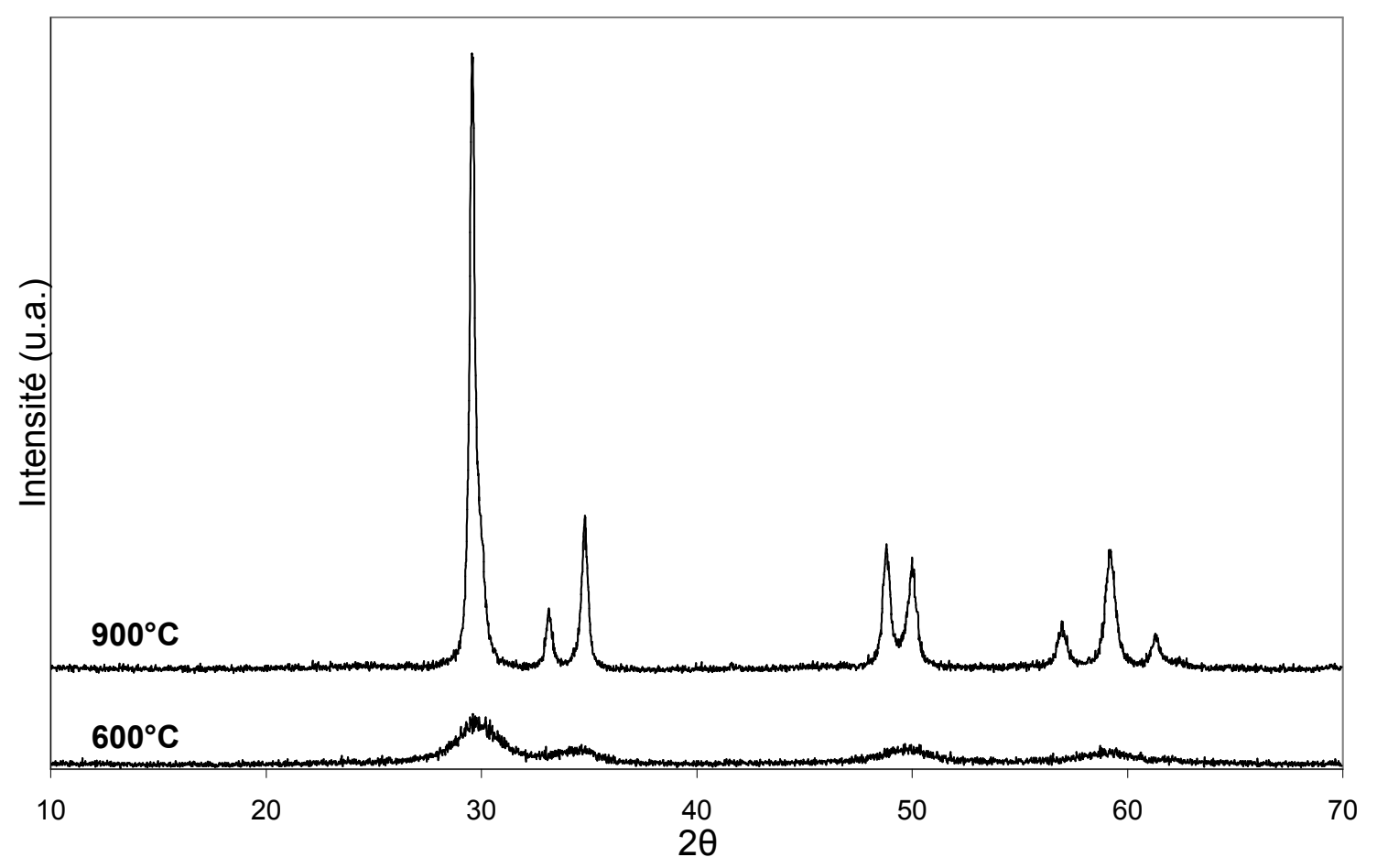

Fig. 3 


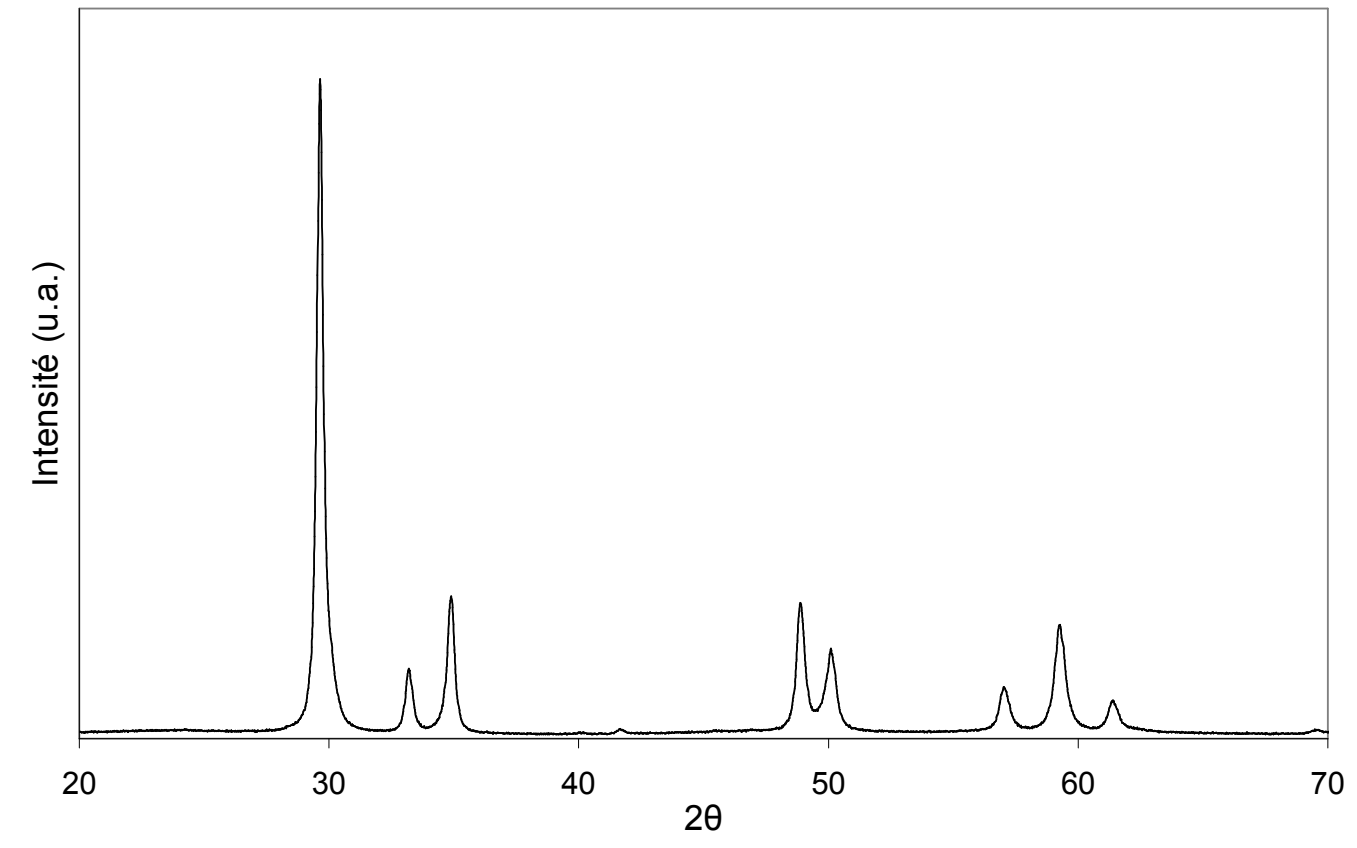

Fig. 4 


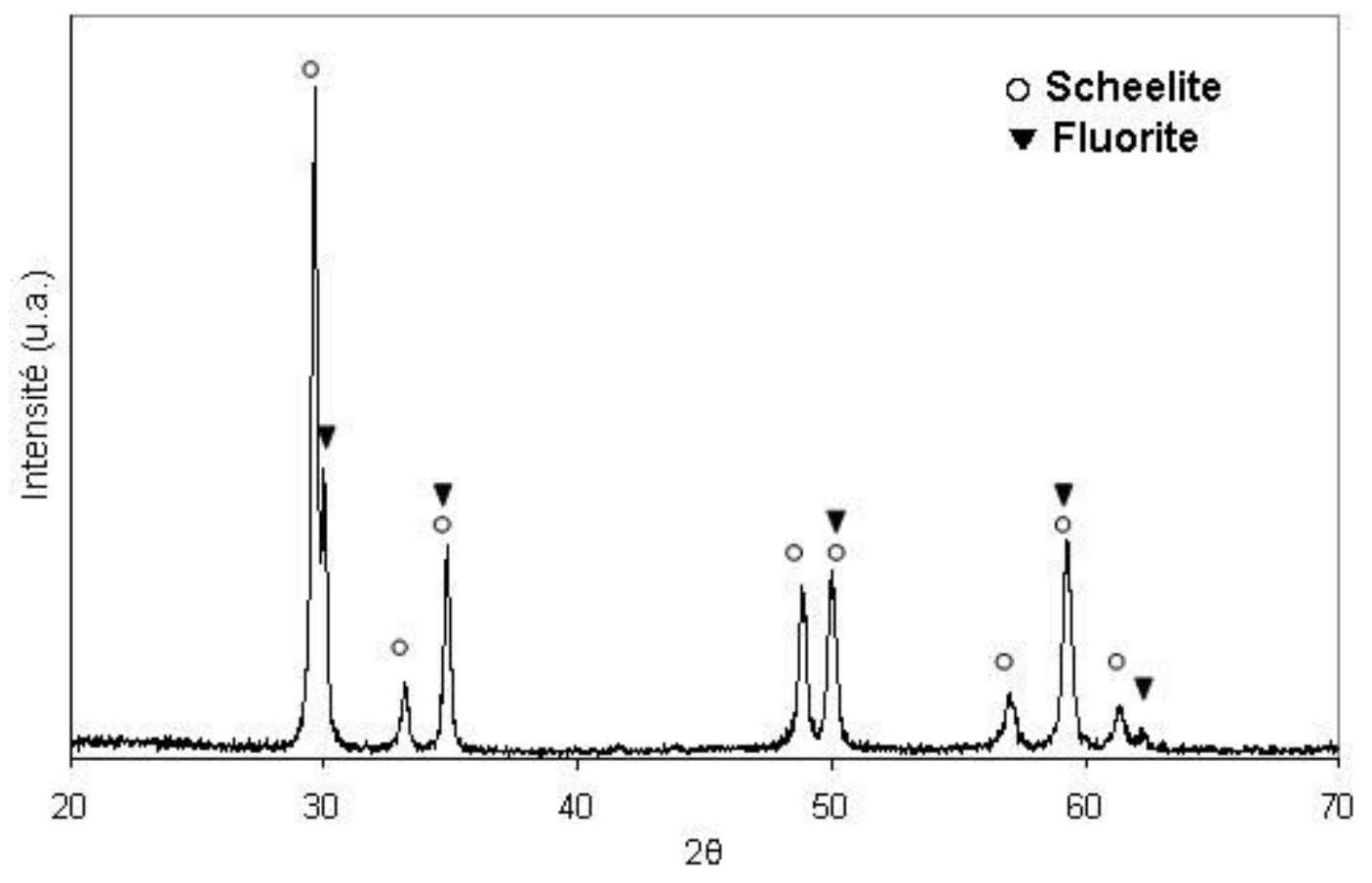

Fig. 5 


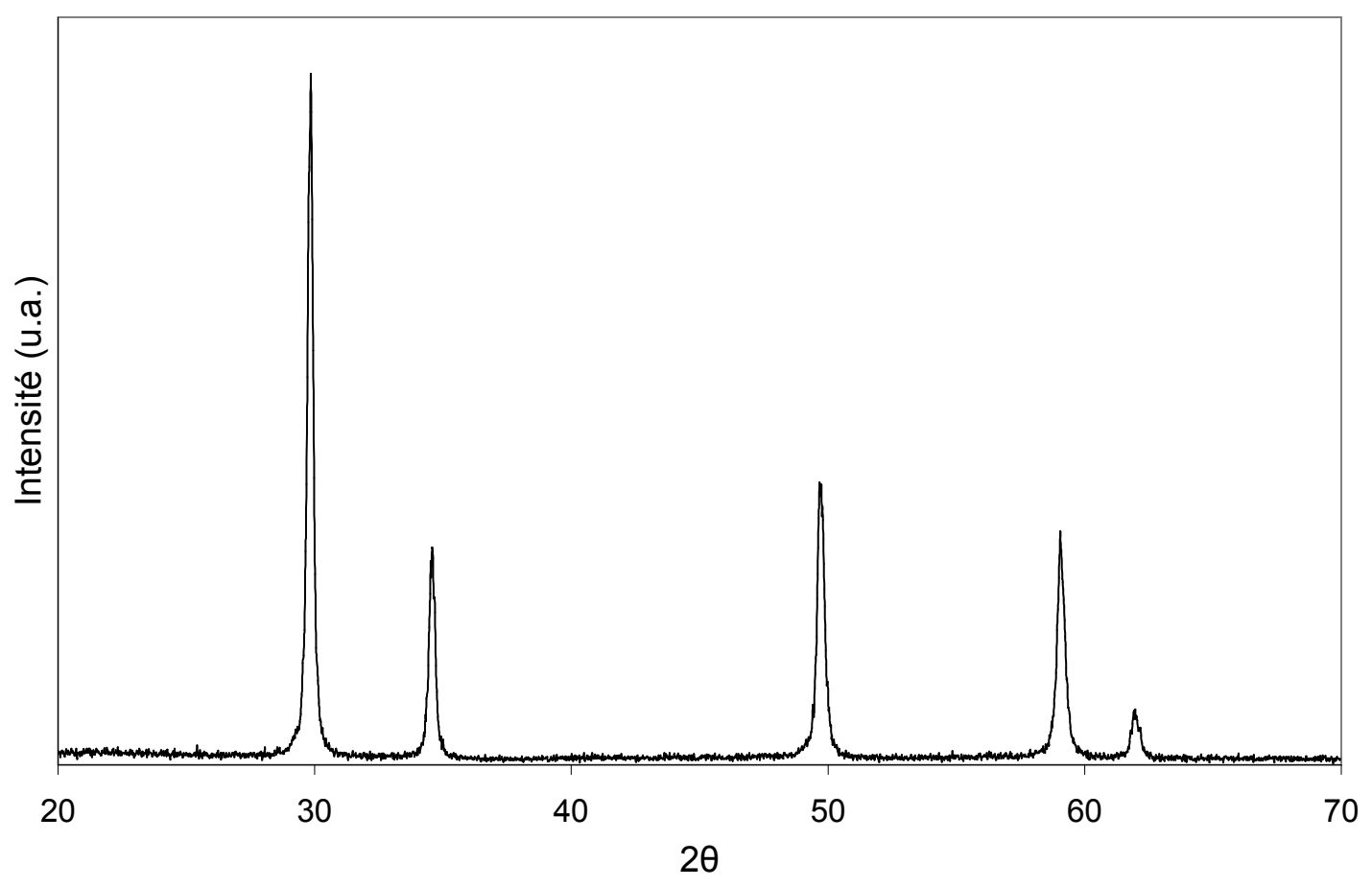

Fig. 6 


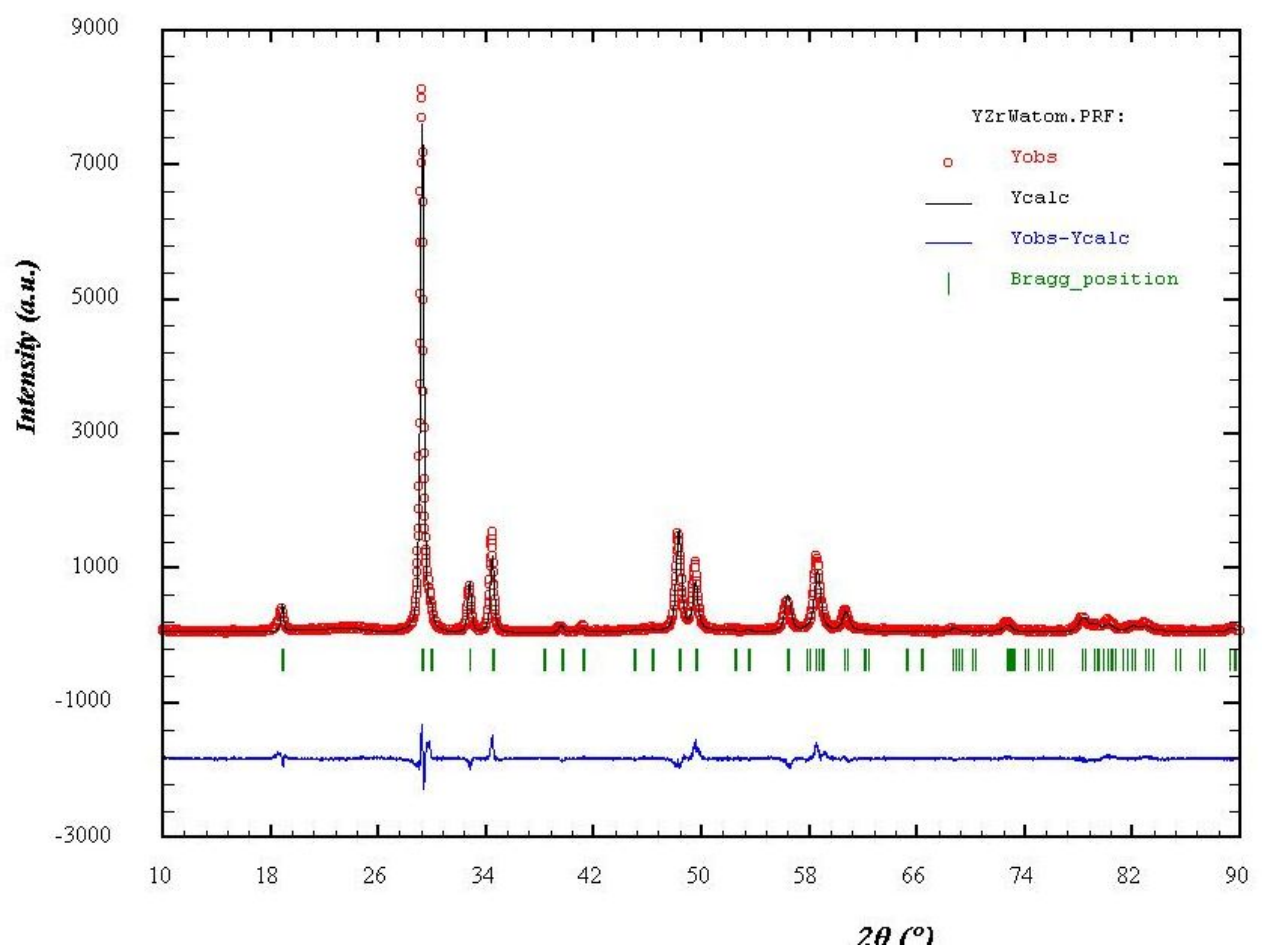

Fig. 7 


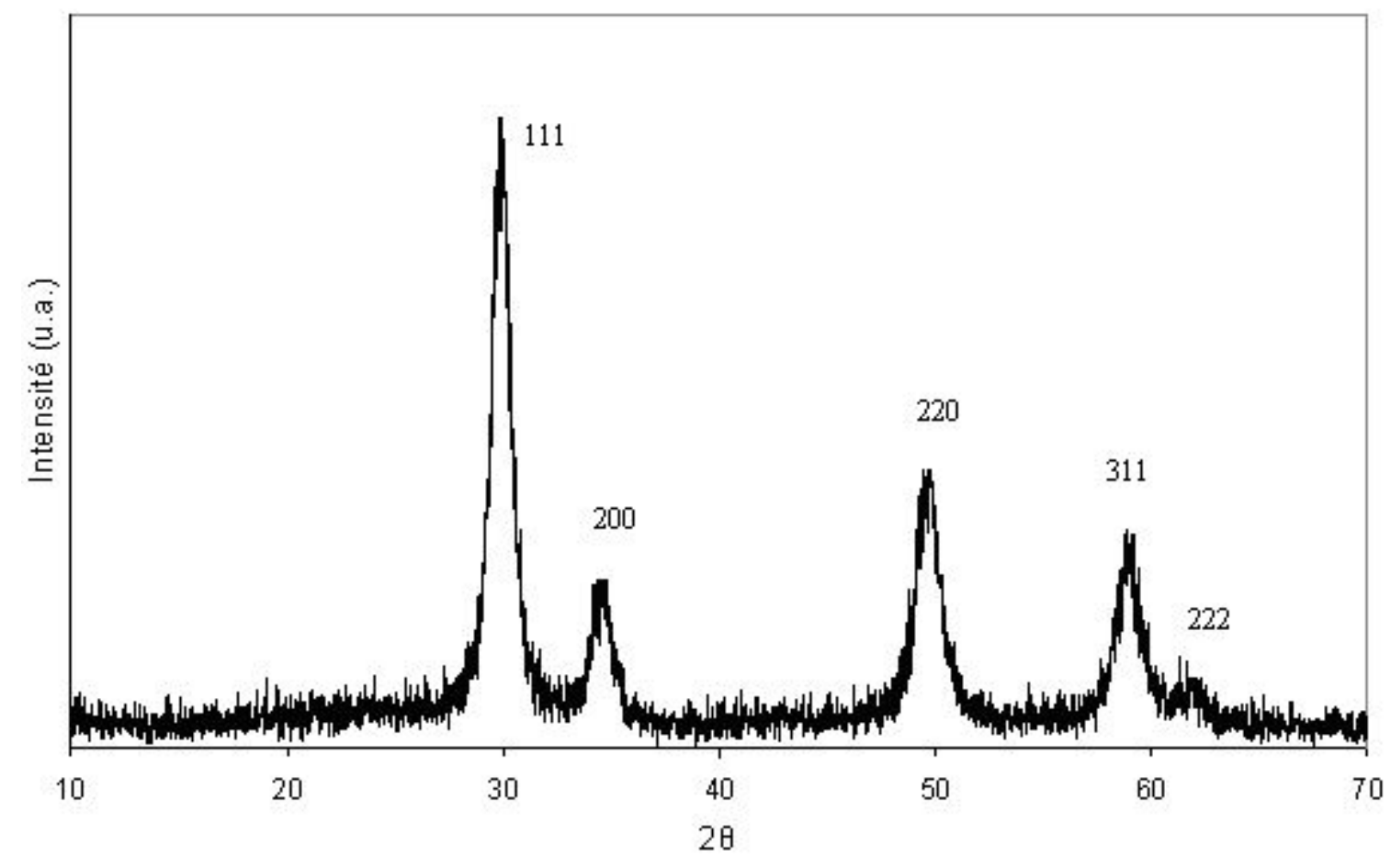

Fig. 8 


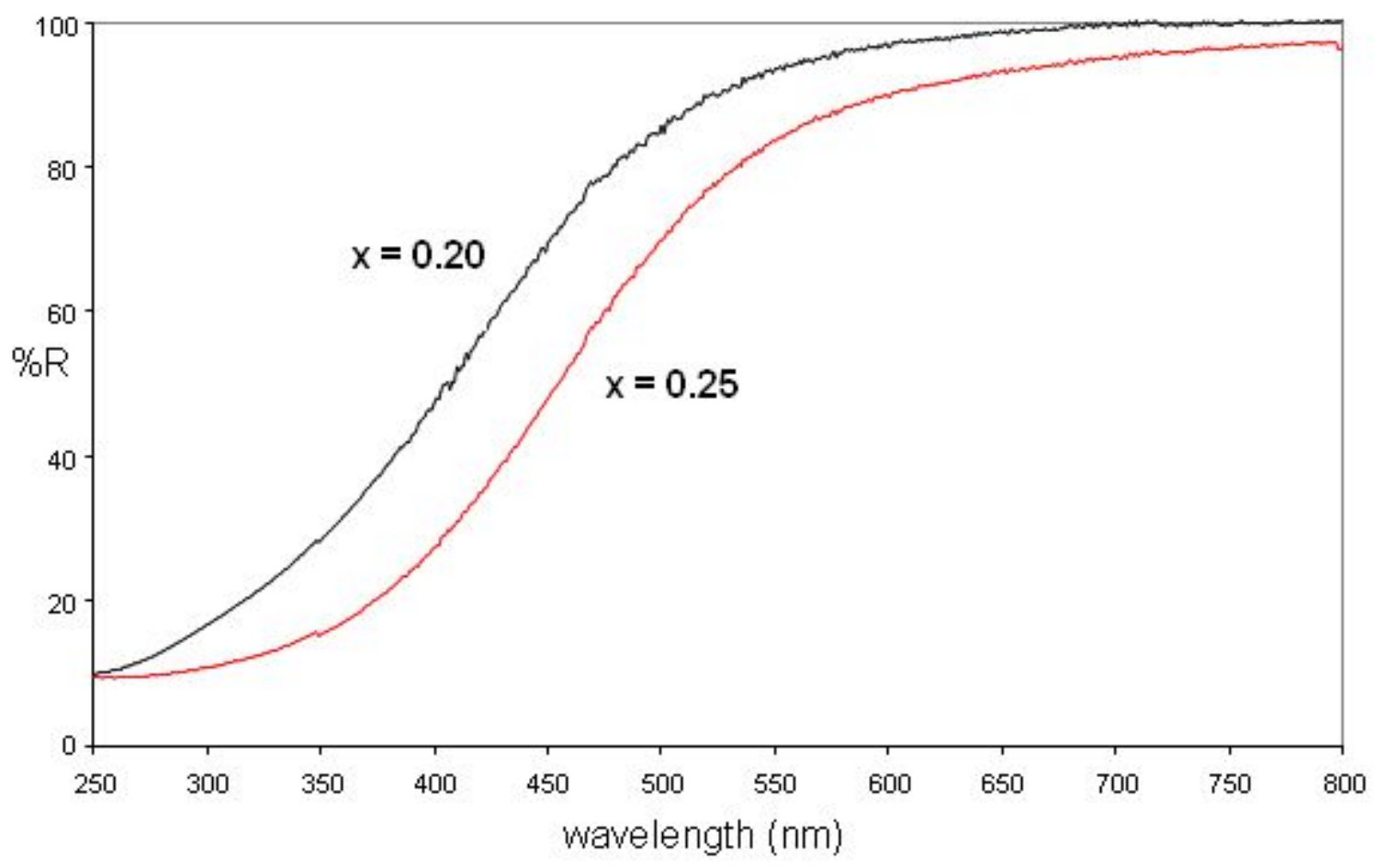

Fig. 9 


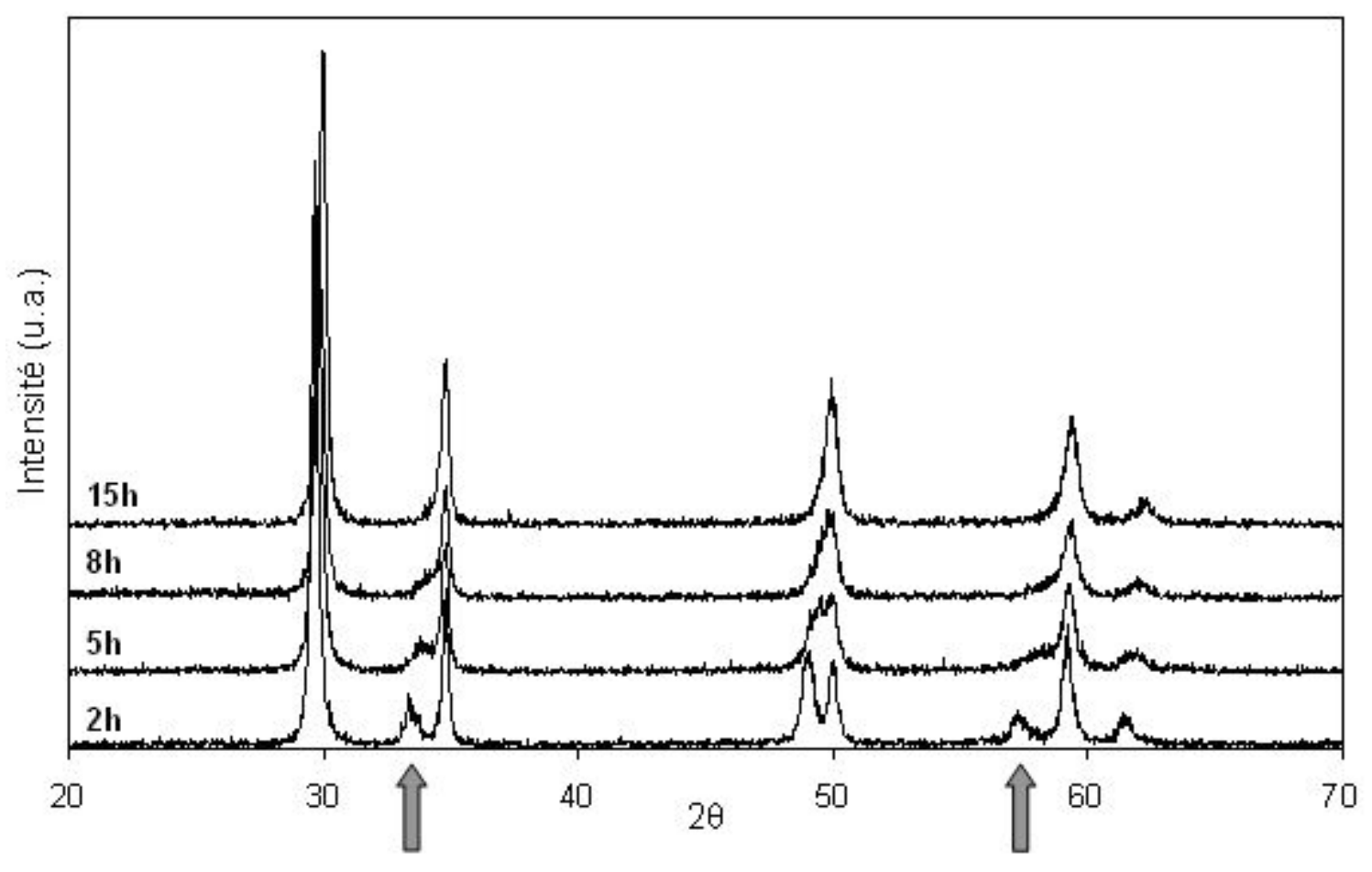

Fig. 10 